Brit. J. prev. soc. Med. (1956), 10, 145-158

\title{
OCCURRENCE AND AETIOLOGY OF LUNG CANCER IN NORWAY IN THE LIGHT OF PATHOLOGICAL ANATOMY*
}

\author{
BY \\ LEIV KREYBERG \\ From the Institute of General and Experimental \\ Pathology, University of Oslo
}

Lung cancer is one of the most fascinating human cancer problems of to-day. That this form of cancer, in a series of countries, has increased to a terrifying degree in this century, is no longer doubted. A number of facts are, however, still unknown, or disputed. As the incidence of lung cancer varies considerably between the many countries which show a definite increase, and as conditions of life, social as well as personal, also vary, it is not unreasonable to expect to derive valuable information regarding the development of lung cancer from comparative geographic studies.

In the present paper an attempt is made to elucidate the lung cancer problem through an epidemio-

"Given as a "Special University Lecture" at the University of London on May 1, 1956. logical study in a country where the rise in incidence is still moderate, and where lung cancer development may be observed nearly in its status nascendi.

Fig. 1 (kindly supplied by Dr. Pedersen of the Norwegian Cancer Registry) shows a very moderate rise in lung cancer mortality in females in town and country from 1929-31 to 1952-54. A slightly more marked rise is seen in males living in the country, but the males living in urban conditions, according to our official administrative designation, show a very different picture. Here, already in the 1930's, a definite rise can be observed, a rise which since the middle of the 1940 's has become very marked.

Seven years ago I planned a systematic study of the lung cancer situation in Norway in close co-operation with the two largest surgical thoracic units in our

Fig. 1.-Mortality from lung cancer per 100,000 of the population in 3-year periods, by sex, in town and country, adjusted to standard population, 1950 (after Pedersen).

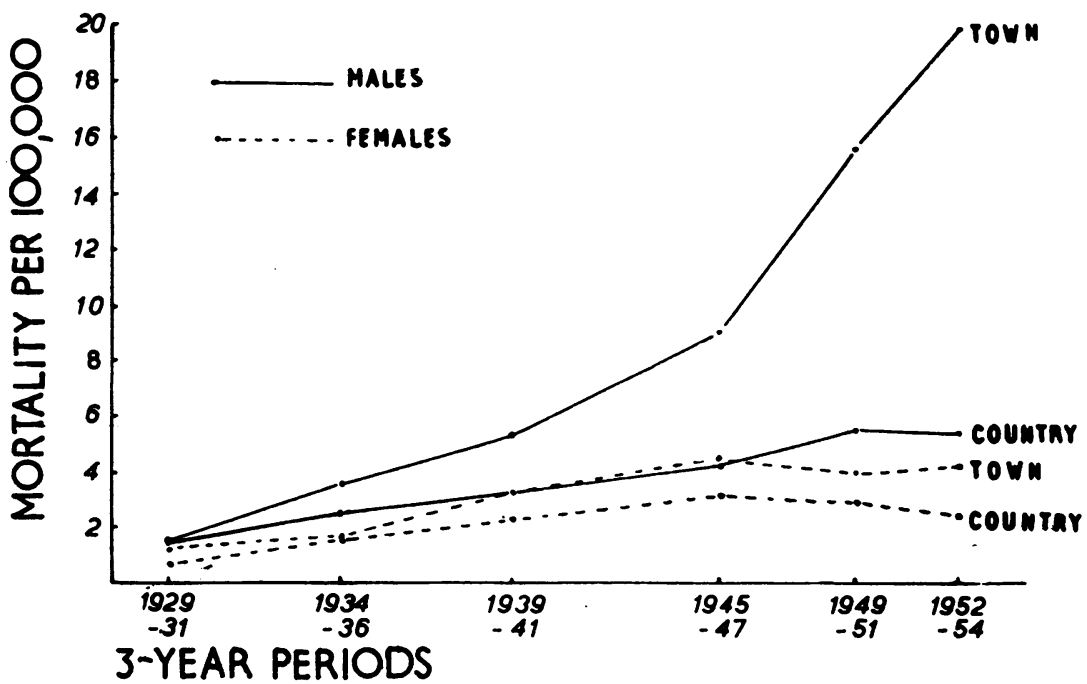


country: the Kirurgisk Avdeling A, Rikshospitalet (Prof. L. Efskind) and the III Avdeling, Ullevål Sykehus (Prof. C. Semb). From the beginning of the study it was evident that the general diagnosis of "lung cancer" includes a variety of tumours. The material for the present investigation has been limited to primary epithelial lung tumours.

Histology.-Considering the very different histological pictures, it would be strange if, within this limited group, different oncological entities were not represented. The first task, therefore, was to make a careful histological analysis of the material, and the next was to study the groups and sub-groups found as regards certain clear biological characteristics and possible differences, such as sex distribution and age. The results of this histological analysis of $\mathbf{3 0 0}$ primary epithelial lung tumours, mainly from surgical cases, are shown in Table I.

\section{TABLE I}

HISTOLOGICAL TYPES AND SEX DISTRIBUTION OF MATERIAL OF PRESENT STUDY

\begin{tabular}{|c|c|c|c|c|c|c|c|}
\hline \multirow{2}{*}{ Group } & \multirow{2}{*}{\multicolumn{4}{|c|}{ Type of Tumour }} & \multicolumn{3}{|c|}{ Sex } \\
\hline & & & & & Male & Female & Total \\
\hline \multirow[t]{2}{*}{ I } & $\begin{array}{l}\text { Squam } \\
\text { Large } \\
\text { Small }\end{array}$ & $\begin{array}{l}\text { cell } \\
\text { carc } \\
\text { carc }\end{array}$ & $\begin{array}{l}\mathrm{rcin} \\
\mathrm{ma} \\
\mathrm{ma}\end{array}$ & $\begin{array}{c}\text { ata } \\
\ldots \\
\ldots\end{array}$ & $\begin{array}{r}147 \\
12 \\
54\end{array}$ & $\begin{array}{l}2 \\
0 \\
3\end{array}$ & $\begin{array}{r}149 \\
12 \\
57\end{array}$ \\
\hline & Total & $\ldots$ & $\ldots$ & $\ldots$ & 213 & 5 & 218 \\
\hline \multirow[t]{2}{*}{ II } & $\begin{array}{l}\text { Adeno } \\
\text { Broncl } \\
\text { Adeno } \\
\text { Salivar }\end{array}$ & $\begin{array}{l}\text { inon } \\
\text { ar ca } \\
\text { a } \\
\text { and }\end{array}$ & $\begin{array}{l}\text { nom } \\
\text { nou }\end{array}$ & $\begin{array}{l}\cdots \\
\cdots \\
\cdots\end{array}$ & $\begin{array}{r}19 \\
7 \\
13 \\
6\end{array}$ & $\begin{array}{r}17 \\
5 \\
12 \\
3\end{array}$ & $\begin{array}{r}36 \\
12 \\
25 \\
9\end{array}$ \\
\hline & Total & $\ldots$ & $\ldots$ & $\ldots$ & 45 & 37 & 82 \\
\hline Total & & $\ldots$ & $\cdots$ & $\cdots$ & 258 & 42 & 300 \\
\hline
\end{tabular}

Sex.-The different incidence of these seven histological types in males and females is most striking. From the point of view of sex distribution the types of tumour fall into two distinct main groups: Group I, in which the male sex is predominant (213:5), and Group II, in which the two sexes are nearly evenly represented $(45: 37)$.

Age.-A study of age incidence reveals further marked differences (Figs 2 and 3). The curves in these Figures indicate "quotients" and not tumour incidence in the usual sense of this designation. A "quotient" is the number of different tumours in the whole material collected during the years 1948-1955, against the background of the size of the population in each age-group in a single year, viz., 1950.

Fig. 2 shows the quotients for squamous cell carcinomata (Curve A) and for large cell and small cell carcinomata jointly (Curve B) in males only. These types of tumour correspond to Group I in
Table I. The curves are nearly identical, and it seems permissible, in spite of certain histological differences, to conclude that these three types represent closely related tumour entities.

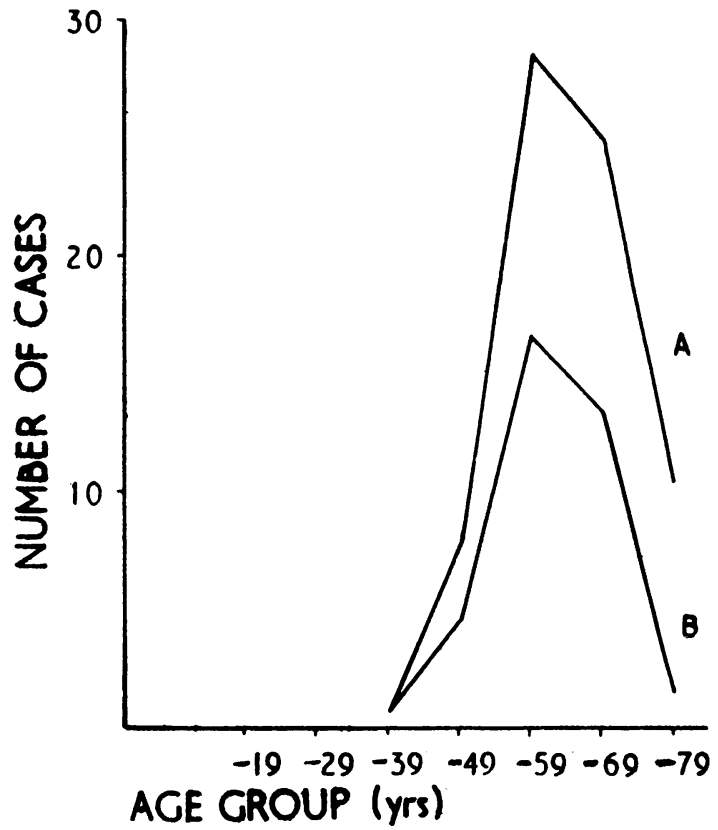

FiG. 2.-Relative frequency of (A) squamous cell, and (B) large and small cell carcinomata in males, by age groups.

In Fig. 3, Curve A represents adenocarcinomata, and Curve B adenomata and salivary gland tumours, including the benign, semi-malignant, and malignant varieties. These curves embrace male as well as female patients. Again, distinct and very different patterns of incidence are found, the adenocarcinomata steadily increasing with advancing years like

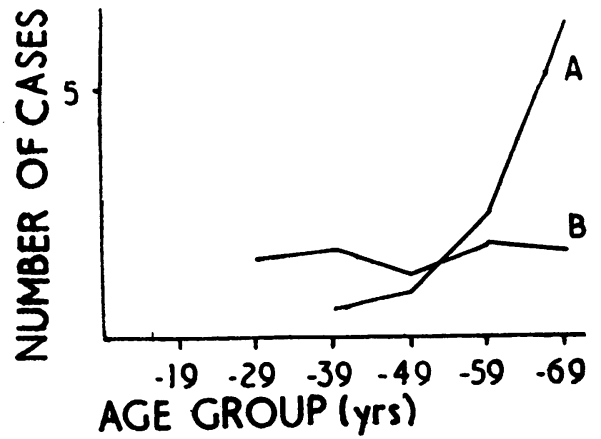

F1G. 3.-Relative frequency of adenocarcinomata, adenomata, and salivary gland tumours, in males and females, by age groups. $\mathbf{A}=$ Adenocarcinomata.

$\mathbf{B}=$ Adenomata and Salivary Gland Tumours. 
many other human tumours, and the adenomata and salivary gland tumours occurring with a uniform frequency in all adult age groups. Our own experience and reports in the literature show that the latter are not infrequent in very young persons, and may even occur in children. Our youngest patient is a boy of 12 years with a malignant adenoma who was reported upon by Harbitz (1937).

DifFERENTIATION OF Group I AND GROUP II.-The main conclusions of this analysis are as follows:

(I) Squamous cell carcinomata, and large and small cell carcinomata, the types of lung tumour generally regarded as connected with special irritants, occur with a marked preponderance in males, and show a characteristic age curve. They very rarely occur before the late thirties. Until the last few years the maximum occurrence was in the fifth decade with a definite decline in the sixth, but recently a shift of this peak to the sixth decade has been observed expecially for squamous cell carcinomata. These observations indicate the existence of a new carcinogenic situation influencing the occurrence of the Group I tumours. In this connexion the analysis of the figures for England and Wales by Korteweg (1951) should be consulted. A similar development has also been recorded in Norway (Fig. 4).

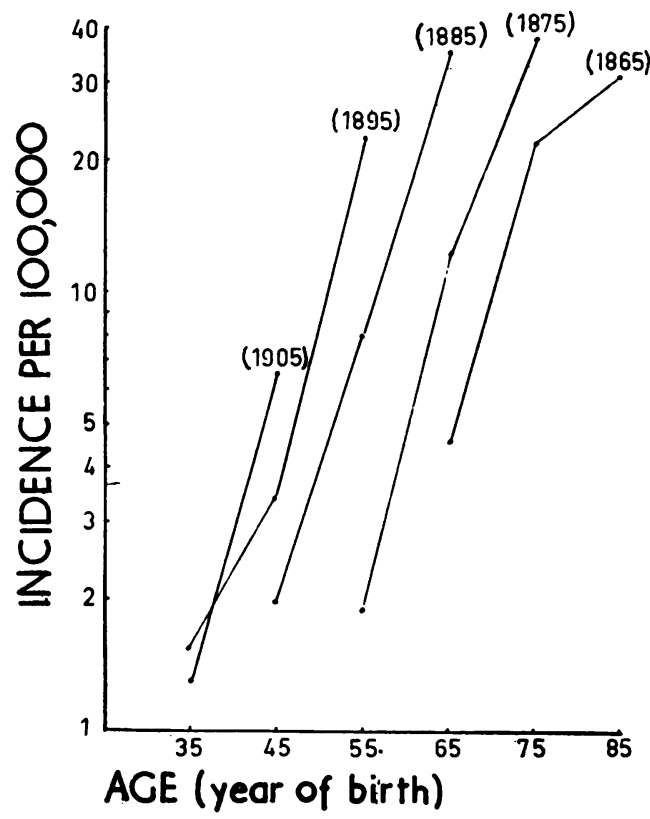

FIG. 4.-Mortality from lung cancer per 100,000 of the population, by age, showing year of birth (after Pedersen).

(II) Adenocarcinomata, according to our diagnostic criteria, embrace malignant tumours composed of more or less atypical, secreting or non-secreting, columnar or irregular polyhedral cells, with a more or less marked gland formation. These tumours, showing a nearly identical sex distribution and a steadily increasing frequency with advancing years, are most probably caused by weak carcinogenic agents, well-established in our society and acting with equal strength in both sexes.

Bronchiolar cell carcinomata form a small group and occur in our material in all adult age groups and in both sexes alike. They may be caused by unknown agents acting at random.

The histological picture, the equal sex incidence, and the lack of preference for any particular age group, together indicate that lung adenomata and salivary gland tumours are caused by accidental factors, presumably of developmental origin.

Lung cancer is accordingly histologically, as well as biologically, a heterogenous group, and this fact has been taken as the basis for the following analysis of the situation in Norway. The lung cancer material has been divided into the two main groups described above:

Group I tumours comprise squamous cell, large-cell, and small-cell carcinomata, with a wide sex difference, increasing numbers in recent years, and an accepted relationship to certain external irritants. Group II tumours comprise adenocarcinomata, bronchiolar cell carcinomata, adenomata, and salivary gland tumours, with an equal sex incidence and no connexion with any known irritants.

Cancer Incidence in Earlier Periods.-In two laboratories (Rikshospital and Oslo City Hospital, Ullevål) two post-mortem series of cases of lung cancer have also been examined, one by Christiansen (1953) and the other by Jakobsen (1953). Table II shows the histological composition of this cadaver material compared with that of the present, mainly surgical, material.

TABLE II

HISTOLOGICAL TYPES AND SEX DISTRIBUTION OF TUMOUR MATERIAL FROM THREE PREVIOUS STUDIES COMPARED WITH PRESENT SERIES

\begin{tabular}{|c|c|c|c|c|c|c|c|}
\hline \multirow{2}{*}{$\frac{\text { Group }}{\text { Sex . }}$} & \multirow{2}{*}{$\frac{\cdots}{\cdots}$} & \multirow{2}{*}{$\frac{.}{\cdots}$} & \multirow{2}{*}{$\frac{.}{\ldots}$} & \multicolumn{2}{|c|}{ I } & \multicolumn{2}{|c|}{ II } \\
\hline & & & & Male & Female & Male & Female \\
\hline \multirow{3}{*}{$\begin{array}{c}\text { Previous } \\
\text { Series }\end{array}$} & $\overline{\text { Chr }}$ & $\begin{array}{l}\text { tiansen } \\
25-44)\end{array}$ & $\cdots$ & 25 & 11 & 15 & 13 \\
\hline & Jac & ssen & . & 46 & 8 & 24 & 22 \\
\hline & $\mathrm{Chr}_{(}$ & tiansen & . & 40 & 4 & 14 & 12 \\
\hline $\begin{array}{c}\text { Present } \\
\text { Series }\end{array}$ & Kre & $\begin{array}{l}\text { berg } \\
48-55)\end{array}$ & .. & 213 & 5 & 45 & 37 \\
\hline
\end{tabular}

The equal occurrence of Group II tumours in the two sexes in each period is in strong contrast to the gradual but marked changes in the incidence of 
Group I tumours, which are especially noticeable from the 1940s onwards.

Table III shows the ratio of Group I to Group II tumours in males in the cadaver and surgical series.

TABLE III

RATIO OF GROUP I TUMOURS TO GROUP II TUMOURS IN MALES IN SAME SERIES AS TABLE II

\begin{tabular}{ll|l|l|l|l}
\hline \multicolumn{1}{c|}{ Author } & & $\begin{array}{c}\text { Period of } \\
\text { Study }\end{array}$ & \multicolumn{2}{|c|}{ Group } & $\begin{array}{c}\text { Ratio } \\
\text { I : II }\end{array}$ \\
\cline { 3 - 5 } & & I & II & \\
\hline Christiansen & $\ldots$ & $(1925-44)$ & 25 & 15 & $1 \cdot 7: 1$ \\
Jakoben & $\cdots$ & $(1937-46)$ & 46 & 24 & $1.9 \vdots 1$ \\
Christiansen & $\cdots$ & $(1945-52)$ & 40 & 14 & $2.9: 1$ \\
Kreyberg & $\cdots$ & $(1948-55)$ & 213 & 45 & $4 \cdot 7: 1$ \\
\hline
\end{tabular}

Domicile. - The incidence of tumours of Groups I and II from the present series in the different counties of Norway is shown in Table IV. If the number of Group II cases is set against the background of the total population in each county, the frequency is seen to be of the same order of magnitude in Oslo, the capital, where the best diagnostic facilities are available, as in the remote counties in the far north. These figures further strengthen the previous indications that the Group II tumours are independent of regional or social conditions. With our present knowledge, they are the basic, and so far unavoidable, tumours of unknown aetiology.

TABLE IV

DISTRIBUTION OF HISTOLOGICAL GROUPS BY COUNTIES

\begin{tabular}{|c|c|c|c|c|c|c|c|}
\hline \multirow{2}{*}{$\begin{array}{l}\text { County of } \\
\text { Domicile }\end{array}$} & \multicolumn{3}{|c|}{ Group I Tumours } & \multicolumn{3}{|c|}{ Group II Tumours } & \multirow{2}{*}{$\frac{\text { Total }}{\substack{\text { Popula- } \\
\text { tion }}}$} \\
\hline & Male & Female & Total & Male & Female & Total & \\
\hline 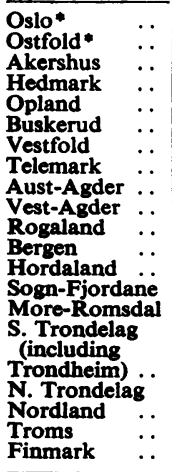 & $\begin{array}{r}77 \\
16 \\
9 \\
4 \\
1 \\
8 \\
14 \\
12 \\
3 \\
9 \\
9 \\
8 \\
3 \\
1 \\
8\end{array}$ & $\begin{array}{l}= \\
\overline{1} \\
= \\
= \\
= \\
= \\
=\end{array}$ & $\begin{array}{r}79 \\
16 \\
9 \\
5 \\
2 \\
8 \\
14 \\
12 \\
3 \\
9 \\
9 \\
8 \\
3 \\
1 \\
8\end{array}$ & $\begin{array}{l}6 \\
4 \\
5 \\
6 \\
2 \\
3 \\
3 \\
2 \\
2 \\
1 \\
1 \\
1 \\
2 \\
2 \\
1 \\
1 \\
1\end{array}$ & $\begin{array}{l}\frac{10}{3} \\
\frac{1}{2} \\
2 \\
\frac{1}{2} \\
\frac{3}{7} \\
1 \\
2 \\
1\end{array}$ & $\begin{array}{r}16 \\
4 \\
8 \\
6 \\
4 \\
5 \\
4 \\
2 \\
4 \\
4 \\
1 \\
2 \\
2 \\
3\end{array}$ & $\begin{array}{r}286,222 \\
178,449 \\
301,149 \\
169,525 \\
154,734 \\
149,948 \\
147,555 \\
131,679 \\
74,861 \\
93,980 \\
202,252 \\
110,424 \\
188,389 \\
96,849 \\
182,859 \\
\\
193,912 \\
105,679 \\
215,972 \\
113722 \\
58,790\end{array}$ \\
\hline $\begin{array}{ll}\text { Sailors } & \ldots \\
\text { Unknown } & \cdots \\
\end{array}$ & $\begin{array}{l}2 \\
4 \\
\end{array}$ & $=$ & $\begin{array}{l}2 \\
4 \\
\end{array}$ & 1 & 1 & $\frac{1}{2}$ & 二 \\
\hline Total & 213 & 5 & 218 & 45 & 37 & 82 & \\
\hline
\end{tabular}

- Part of greater Oslo, including important industrial areas, was ormerly situated in Akershus and the figures presented in this Table refer to conditions before the inclusion of these areas in Oslo.
The Group II tumours in our material are thus fairly representative for the whole country. If this holds good for the Group II tumours, then the figures for the Group I tumours should also be representative, because all lung tumour patients show very similar symptoms, have passed through the same diagnostic procedures, and have been given the same diagnostic opportunities. The histological diagnosis separating the two groups is a late link in the diagnostic chain, often not obtained before the patients have arrived at the special hospital.

The incidence of Group I tumours is remarkably different in different counties; they are most numerous in Oslo, and next, through to a lesser degree, in those counties with the most urban and industrial areas.

Each patient was examined with respect to domicile from decade to decade, and the population was found to be remarkably stable until recently, when the flow from the countryside to the towns and industrial centres has increased.

Types of domicile are shown in Table V, Section A (opposite):*
(i) Countryside.
(ii) Smaller non-industrial towns.
(iii) Industrial centres.
(iv) Larger towns.

The Group II tumours are evenly distributed between the two sexes, regardless of domicile. The ratios of Group I to Group II tumours in males are lowest in the country and highest in the larger towns. The ratio in the country corresponds to the ratio in the early post-mortem series (Table III). The smaller non-industrial towns, mainly commercial and administration centres, show a somewhat higher ratio than the industrial centres, a result which at first I found puzzling.

Air Pollution and Urban and RuRal SuRROUNDINGS.-These types of domicile were then examined as regards air pollution (Table V, Section B, opposite).

The countryside and smaller non-industrial towns were classified as having "fresh" air ([i] and [ii]), and the industrial centres and larger towns as having "polluted" air ([iii] and [iv]). The ratio in males is much higher for the latter than for the former.

When the same material is classified into "rural" or "urban" surroundings (Table V, Section C, opposite), the ratio in males is even greater.

These figures do not permit any decisive conclusions as to the influence of air pollution in the Norwegian material. In co-operation with Dr. J. M. Campbell of The Department of Pathology,

\footnotetext{
- This Table excludes sailors and patients of unknown domicile.
} 
TABLE V

DISTRIBUTION OF HISTOLOGICAL GROUPS BY PATIENT'S DOMICILE

\begin{tabular}{|c|c|c|c|c|c|c|c|c|c|c|c|c|}
\hline \multirow{2}{*}{$\frac{\text { Group }}{\text { Sex }}$} & \multirow{2}{*}{$\frac{\cdots}{\cdots}$} & \multirow{2}{*}{$\cdots$} & \multirow{2}{*}{$\cdots$} & \multirow{2}{*}{$\frac{\cdots}{\cdots}$} & \multirow{2}{*}{$\frac{\cdots}{\cdots}$} & \multicolumn{3}{|c|}{$\mathbf{I}$} & \multicolumn{3}{|c|}{ II } & \multirow{2}{*}{$\begin{array}{l}\text { Ratio of I : II } \\
\text { in Males }\end{array}$} \\
\hline & & & & & & Male & Female & Total & Male & Female & Total & \\
\hline \multirow{4}{*}{$\begin{array}{c}\text { (A) } \\
\text { Type of } \\
\text { Domicile }\end{array}$} & \multicolumn{2}{|c|}{ (i) Country } & $\cdots$ & $\cdots$ & $\cdots$ & 31 & 2 & 33 & 17 & 17 & 34 & $1 \cdot 8: 1$ \\
\hline & \multicolumn{4}{|c|}{ (ii) Non-Industrial Towns } & . & 45 & 1 & 46 & 8 & 5 & 13 & $5 \cdot 6: 1$ \\
\hline & \multicolumn{4}{|c|}{ (iii) Industrial Centres } & $\ldots$ & 26 & 0 & 26 & 6 & 3 & 9 & $4 \cdot 3: 1$ \\
\hline & \multicolumn{3}{|c|}{ (iv) Larger Towns * } & $\cdots$ & $\cdots$ & 87 & 2 & 89 & 7 & 11 & 18 & $12 \cdot 4: 1$ \\
\hline $\begin{array}{l}\text { (B) } \\
\text { Air }\end{array}$ & \multicolumn{3}{|c|}{$\begin{array}{l}\text { Fresh (i, ii) } \\
\text { Polluted (iii, iv) }\end{array}$} & $\begin{array}{l}\cdots \\
\cdots\end{array}$ & 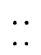 & $\begin{array}{r}76 \\
113\end{array}$ & $\begin{array}{l}3 \\
2\end{array}$ & $\begin{array}{r}79 \\
115\end{array}$ & $\begin{array}{l}25 \\
13\end{array}$ & $\begin{array}{l}22 \\
14\end{array}$ & $\begin{array}{l}47 \\
27\end{array}$ & $\begin{array}{l}3 \cdot 0: 1 \\
8 \cdot 7: 1\end{array}$ \\
\hline $\begin{array}{c}\text { (C) } \\
\text { Surroundings }\end{array}$ & \multicolumn{3}{|c|}{$\begin{array}{l}\text { Rural (i) } \\
\text { Urban (ii, iii, iv) }\end{array}$} & $\begin{array}{l}\cdots \\
\cdots\end{array}$ & 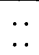 & $\begin{array}{r}31 \\
158\end{array}$ & 2 & $\begin{array}{r}33 \\
161\end{array}$ & $\begin{array}{l}17 \\
21\end{array}$ & $\begin{array}{l}17 \\
19\end{array}$ & $\begin{array}{l}34 \\
40\end{array}$ & $\begin{array}{l}1 \cdot 8: 1 \\
7 \cdot 5: 1\end{array}$ \\
\hline
\end{tabular}

* Oslo, Bergen, Trondheim.

St. Bartholomew's Hospital, London, a study of the quality and the quantity of suspended matters polluting the air was carried out in Oslo and a few other Norwegian localities (to be published). The qualitative composition of the dust and soot retained on a filter paper after forced passage of air, is very like that found in English towns and in the English countryside (Fig. 5).

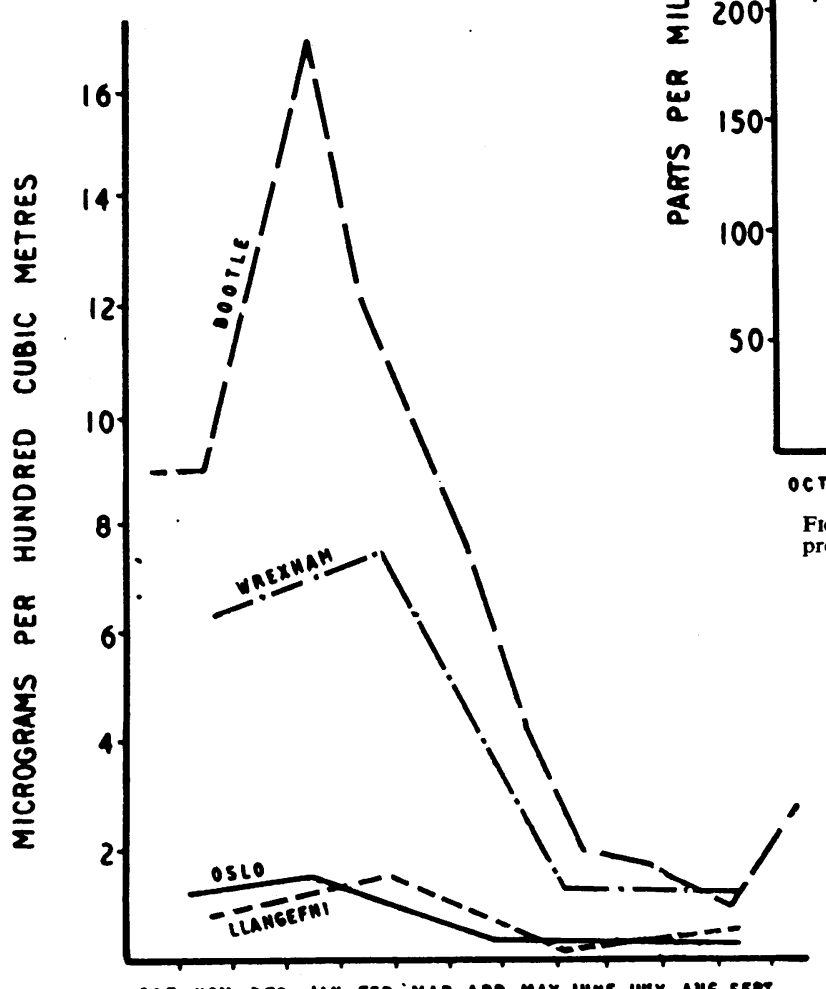

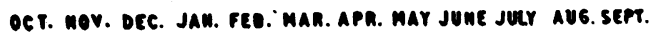

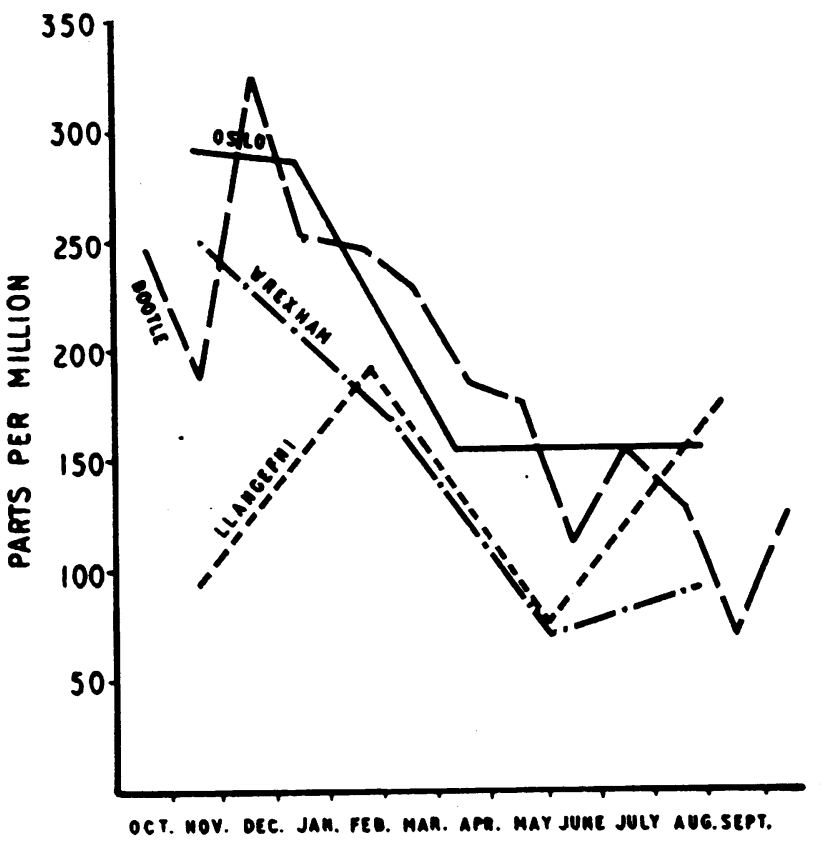

Fig. 5.-Monthly concentration of $3: 4$ benzpyrene as a proportion of the suspended impurities in the atmosphere in Oslo, Bootle, Llangefni, and Wrexham.

Quantitatively, it is found that the degree of pollution is very much lower, the figures for Oslo, the largest town in Norway, being only of the same order of magnitude as those in Llangefni, a small coastal village in Anglesey, North Wales (Fig. 6).

Fig. 6.-Monthly concentration of $3: 4$ benzpyrene in the air in Oslo, Bootle, Llangefni, and Wrexham. 
A direct comparison of the lung cancer situation in Great Britain and Norway involves many known and unknown fallacies. Stocks and Campbell (1955), and all the earlier writers, treat "lung cancer" as an entity, as do our official mortality statistics. In both countries lung cancer mortality in rural areas has shown a negligible increase in the last 20 to 30 years, in a dramatic contrast to that in the towns. The present Norwegian analysis shows that this urban increase has been caused by an increase in Group I tumours only. Now, if air pollution could be accepted as an important causative factor for lung cancer in Great Britain, it would be difficult to accept such a conclusion as regards conditions in Norway. The very marked, nearly explosive, rise in the frequency of Group I tumours in males in Oslo, especially in the last 10 years, cannot be explained by a corresponding increase in air pollution in Oslo, beginning some $20-40$ years ago (which is the time factor to be used for such calculations) and finally resulting in a pollution no greater than that found in a coastal village in Wales. In addition, no increase in lung cancer in females has been observed in Oslo in the same period.

OCCUPATION.-The incidence of lung tumours has also been examined in relation to the occupations of the patients (Table VI).

In most cases categorization was simple because the patients had followed a consistent line in their occupational life. Where the patient had changed his occupation, an estimate was made of the individual situation, and he was listed under the more specialized occupation if such work had lasted for 10 years or more. If, for instance, a ship's stoker had worked as such for $\mathbf{1 0}$ years or more and later came ashore and settled as a fisherman, he would be listed as a stoker. If, on the other hand, a former sailor had come ashore and worked in a copper mine for 10 years or more, he would be listed as a miner. Such doubtful cases were rare enough not to invalidate the general conclusions. This mode of approach was chosen in the hope of discovering any marked accumulations of lung tumour cases in any special occupation.

Table VI again indicates the even distribution of Group II tumours in the population, the largest numbers occurring in the occupations with the largest number of men. The Group I tumours show a more irregular distribution, the low numbers in farmers being most conspicuous. No special occupation is overwhelmingly represented, except perhaps workers in mechanical workshops, including
TABle VI

DISTRIBUTION OF HISTOLOGICAL GROUPS BY PATIENT'S OCCUPATION AND SEX

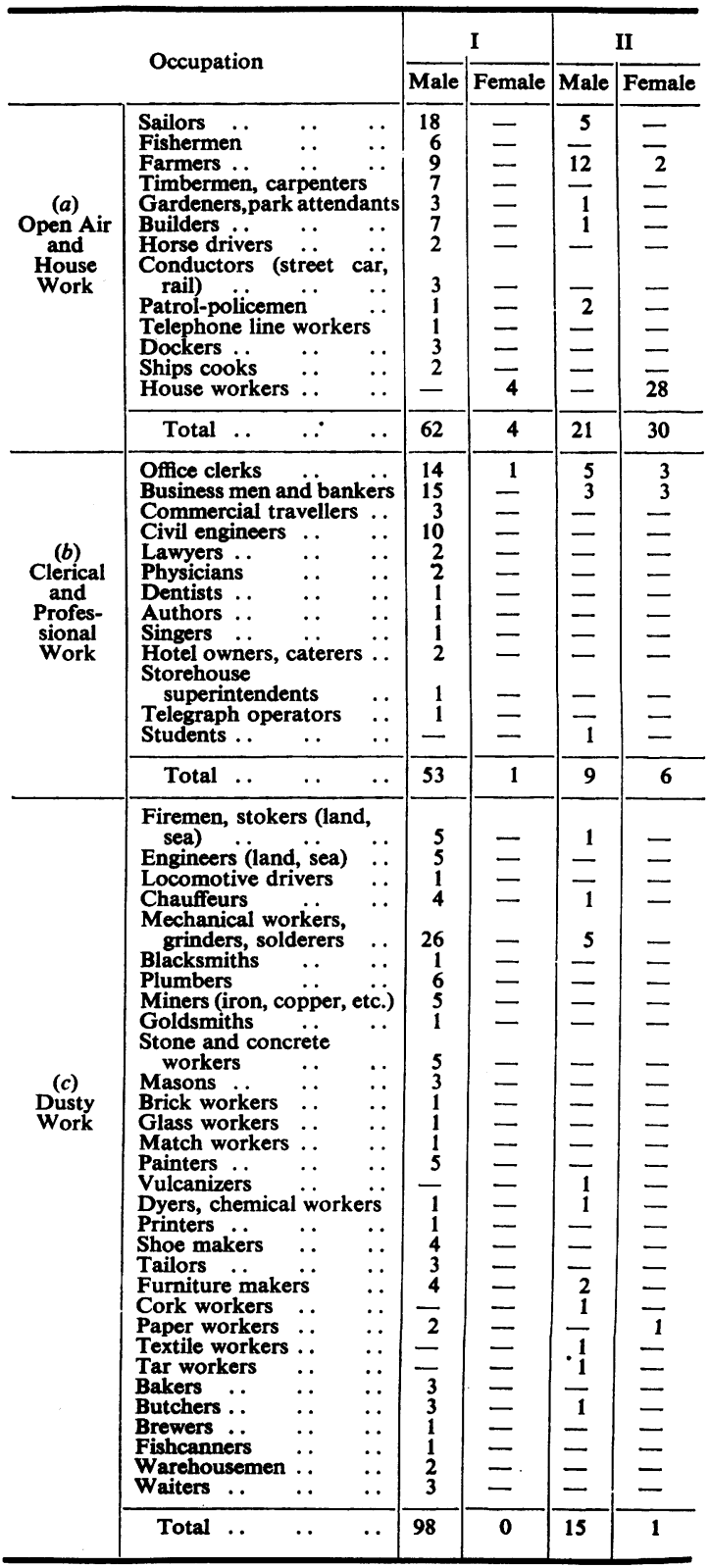

solderers, welders, etc., but the total number is too small for accurate analysis. It may also be noticed that cases in civil engineers are comparatively numerous.

In order to assess the lung cancer risks on a 
broader basis, the different occupations have been grouped in three main categories;
(a) "Open air" and "house" work,
(b) "Clerical" and "professional" work,
(c) "Dusty" work.

When these categories had been decided upon and delimited, the Statistisk Sentralbyrå was kind enough to furnish a fairly accurate estimate of their numbers in the total population.

The analysis in Table VI was made in order to find whether certain occupations were especially liable to be connected with the development of lung tumours. The figures from the Statistisk Sentralbyrå give the situation at one particular time, and our patients were re-grouped accordingly so that each was listed under the occupation in which he was actually engaged at the time of diagnosis. This resulted in the following changes:

Sixteen men of 70 years old or more who had retired had previously been listed under their previous occupations, and thirteen men had changed their occupation, though several of these remained in the same main category. When the final corrections were made, the figure for "open air" and "house" work was reduced by four, with a corresponding increase of two in each of the other two categories. There was no change in the occupations of the women.

As the female cases of lung cancer in Norway nearly all manifest Group II tumours, it is of great interest, as a control of the figures received from the Statistisk Sentralbyrå, to examine the incidence of these tumours by sex and occupation (Table VII). Considering the restricted number of cases, a remarkable correspondence is found between the number to be expected if no special factors were involved, and the number observed. Our present material included only five cases of Group I tumours in females; the incidence of these tumours also is such as would be expected if no occupational hazards were involved.

The figures for males, however, show a very different picture. Group II tumours occur, as in the females, in proportion to the size of each main occupational category. If the frequency in "open air" and "house" workers is set as index 1.0 , the corresponding indices for the two other categories are 0.8 and 1.0 respectively.

Group I tumours are much less frequent among male "open air" and "house" workers than in the two other main occupational categories, and if similar indices of frequency are calculated, an index of 1.0 for the first category corresponds to indices of 1.8 and 2.3 respectively for the other two categories.

In the same material the ratios of Group I tumours to Group II tumours in males are $2.8: 1$, $6 \cdot 1: 1$, and $6 \cdot 7: 1$ (Table VIII).

TABLE VIII

RATIO OF GROUP I TUMOURS TO GROUP II TUMOURS BY OCCUPATION, MALES

\begin{tabular}{|c|c|c|c|c|}
\hline \multirow{2}{*}{\multicolumn{2}{|c|}{ Occupation }} & \multicolumn{2}{|c|}{ Group } & \multirow{2}{*}{$\begin{array}{l}\text { Ratio } \\
\text { I : II }\end{array}$} \\
\hline & & I & II & \\
\hline "Open air" and "House" .. & $\ldots$ & 58 & 21 & $2 \cdot 8: 1$ \\
\hline "Clerical" and "Professional" & $\cdots$ & 55 & 9 & $6 \cdot 1: 1$ \\
\hline "Dusty" & $\cdots$ & 100 & 15 & $6.7: 1$ \\
\hline
\end{tabular}

The two different materials for control (viz. the general population and the lung tumour groups inter se) give nearly identical results, and this greatly strengthens the assumption that the differences found are real.

These findings neither prove nor exclude the possibility that occupational "dust" per se is an

TABLE VII

DISTRIBUTION OF HISTOLOGICAL GROUPS BY MAIN OCCUPATIONAL CATEGORIES AND SEX, AS PERCENTAGE OF TOTAL POPULATION IN EACH TYPE OF WORK

\begin{tabular}{|c|c|c|c|c|c|c|c|c|c|c|}
\hline \multirow{3}{*}{ Sex } & \multirow{3}{*}{\multicolumn{2}{|c|}{ Occupation }} & & & \multicolumn{2}{|c|}{ Total Population } & \multicolumn{4}{|c|}{ Group } \\
\hline & & & & & \multirow{2}{*}{ Number } & \multirow{2}{*}{ (Per cent.) } & \multicolumn{2}{|c|}{ I } & \multicolumn{2}{|c|}{ II } \\
\hline & & & & & & & No. & Per cent. & No. & Per cent. \\
\hline \multirow[t]{2}{*}{ Female } & $\begin{array}{l}\text { "Open air" and "F } \\
\text { "Clerical" and "Pr } \\
\text { "Dusty" . }\end{array}$ & $\begin{array}{l}\text { se" } \\
\text { ssional" } \\
\ldots\end{array}$ & $\begin{array}{l}\dot{*} \\
\cdots\end{array}$ & & $\begin{array}{l}854,005 \\
173,406 \\
70,869 \\
\end{array}$ & $\begin{array}{r}77 \cdot 8 \\
15 \cdot 8 \\
6 \cdot 4 \\
\end{array}$ & $\begin{array}{l}4 \\
1 \\
0\end{array}$ & $\begin{array}{r}80.0 \\
20.0 \\
- \\
\end{array}$ & $\begin{array}{r}30 \\
6 \\
1 \\
\end{array}$ & $\begin{array}{r}81 \cdot 1 \\
16 \cdot 2 \\
2 \cdot 7 \\
\end{array}$ \\
\hline & Total $\ldots$ & $\cdots$ & $\cdots$ & $\cdots$ & $1,098,280$ & 100 & 5 & 100 & 37 & 100 \\
\hline \multirow[t]{2}{*}{ Male } & $\begin{array}{l}\text { "Open air" and "Y } \\
\text { "Clerical" and "Pr } \\
\text { "Dusty" . }\end{array}$ & $\begin{array}{l}\text { se" } \\
\text { ssional", } \\
\ldots\end{array}$ & $\begin{array}{l}\cdots \\
\cdots\end{array}$ & $\begin{array}{l}\ddot{*} \\
\dot{*}\end{array}$ & $\begin{array}{l}467,494 \\
244,163 \\
341,634 \\
\end{array}$ & $\begin{array}{l}44 \cdot 3 \\
23 \cdot 3 \\
32 \cdot 4\end{array}$ & $\begin{array}{r}58(1)^{*} \\
55(1 \cdot 8) \\
100(2 \cdot 3) \\
\end{array}$ & $\begin{array}{l}27 \cdot 2 \\
25 \cdot 8 \\
47 \cdot 0 \\
\end{array}$ & $\begin{array}{l}21(1)^{*} \\
9(0 \cdot 8) \\
15(1) \\
\end{array}$ & $\begin{array}{l}46 \cdot 7 \\
20 \\
33 \cdot 3 \\
\end{array}$ \\
\hline & Total $\ldots$ & . & $\cdots$ & $\cdots$ & $1,053,291$ & 100 & 213 & 100 & 45 & 100 \\
\hline
\end{tabular}

* Index of frequency for males given in brackets. 
important factor in augmenting the chance of developing Group I lung cancers, but two observations tend to reduce the probability of such an assumption: first, the considerably increased risk which is also found in recent years among "clerical" and "professional" workers not exposed to such dusts, and secondly, the wide range of "dusty" occupations involved and the few victims within each special occupation. Our findings are so far in accord with those of Doll (1953) and Lickint (1953).

Considering the fact that in Norway the increase in Group I lung tumours in males is intimately connected with the urban mode of life and has no demonstrable connexion with a general air pollution, as well as the fact that males doing "clerical" and "professional" work are affiicted nearly as often as workers in "dusty" surroundings, it seems reasonable to suppose that the new carcinogenic situation is linked to the personal life habits of men, rather than to general exposure to smoke, fumes, and dusts from streets, motor vehicles, urban air, and industrial undertakings.

Furthermore, this analysis also indicates that sufferers with Group II lung tumours represent the most suitable control material for the study of aetiological factors in the development of Group I tumours.

ToBACCO-SMOKING. - The tobacco-smoking factor has been carefully examined in this series of cases. A questionnaire was completed, giving present age, age when smoking was commenced and (where applicable) when it was ended, and amount of tobacco smoked. The last item was given as number of cigarettes or cigars a day, or as grammes smoked per week in the case of pipe-smoking and handrolling of cigarettes, a cigarette counting as $1 \mathrm{~g}$., and a cigar as $5 \mathrm{~g}$.

The first part of the analysis takes the form of a comparison of the smoking habits of the lung tumour patients with the control material presented by $H$. J. A. Kreyberg (1954). The lung tumour material was histologically typed, placed in Group I or Group II, and tabulated according to the smoking levels as used in the control study. Next, a calculation was made of the number of cases to be expected in the different smoking levels of the control material if as many individuals were represented as in the lung tumour material, age group (Table IX).

\section{Group II Tumours}

Table IX shows that the figures for females are nearly identical in the two series, indicating that tobaccosmoking is of no importance as an aetiological facor in the development of Group II tumours in females.

The figures for males are nearly identical and the same conclusions may be drawn.

\section{Group I Tumours}

Table IX shows that in males the picture is very different. There are significantly fewer non-smokers, and a higher number of heavy smokers; even for the other smoking levels the same tendency can be observed, with a systematic deviation towards the extremes.

These figures closely follow the pattern observed by many other workers, and the findings point to a close relationship between tobacco-smoking and the development of Group I tumours (often designated "epidermoid" tumours) in males.

The figures for Group I tumours in females are very small and no comment is necessary.

As the Group I and Group II tumours in males seem to behave so differently in relation to tobaccosmoking, it may be of some interest to compare the two groups in more detail. The pertinent figures for males are given in Table $\mathrm{X}$.

TABLE X

SMOKING LEVELS OF GROUP I AND GROUP II TUMOUR PATIENTS (MALES)

\begin{tabular}{|c|c|c|c|c|c|c|c|c|c|c|c|}
\hline \multicolumn{2}{|c|}{$\begin{array}{c}\text { Smoking } \\
\text { Level } \\
\text { (g.) }\end{array}$} & 0 & $1-4$ & 5-9 & $10-14$ & $15-19$ & $20-24$ & $25-29$ & $30-49$ & $50+$ & Total \\
\hline \multirow{2}{*}{ Group } & I & 3 & 4 & 41 & 78 & 29 & 20 & 15 & 18 & 5 & 213 \\
\hline & II & 3 & 5 & 14 & 12 & 5 & 1 & 4 & 0 & 1 & 45 \\
\hline \multicolumn{2}{|c|}{$\begin{array}{l}\text { Group I } \\
\text { Tumours } \\
\text { Related to } \\
\text { Smoking }\end{array}$} & - & - & 27 & 66 & 24 & 19 & 11 & 18 & 4 & 169 \\
\hline
\end{tabular}

TABLE IX

TOBACCO-SMOKING AND INCIDENCE OF LUNG TUMOURS COMPOSED WITH GENERAL POPULATION

\begin{tabular}{|c|c|c|c|c|c|c|c|c|c|c|c|c|}
\hline \multirow{2}{*}{ Sex } & \multicolumn{2}{|l|}{ Group } & \multicolumn{5}{|c|}{ I } & \multicolumn{5}{|c|}{ IJ } \\
\hline & Smoking Level (g.) & $\ldots$ & 0 & $1-14$ & $15-24$ & $25+$ & Total & 0 & $1-14$ & $15-24$ & $25+$ & Total \\
\hline \multirow{2}{*}{ Male } & Lung Tumours & $\ldots$ & 3 & 123 & 49 & 38 & 213 & 3 & 31 & 6 & 5 & 45 \\
\hline & Controls (General P & opulation) & $28 \cdot 2$ & $128 \cdot 6$ & 41.9 & $14 \cdot 6$ & 213 & 6.7 & $26 \cdot 1$ & 9.4 & $2 \cdot 8$ & 45 \\
\hline \multirow{2}{*}{ Female } & Lung Tumours & $\ldots$ & 3 & 1 & 1 & 0 & 5 & 27 & 9 & 1 & 0 & 37 \\
\hline & Controls (General P & opulation) & $4 \cdot 2$ & 0.7 & 0.1 & 0 & 5 & $28 \cdot 5$ & $7 \cdot 3$ & $1 \cdot 1$ & 0.1 & 37 \\
\hline
\end{tabular}


It has already been assumed that these two "groups" are probably representative of the real occurrence of the histological types for the whole country during the period of this study. We may, therefore, also assume that the relationship between the two groups is representative.

The non-smoking part of the male population is represented in Table $X$ by three cases from each group, giving a ratio of $1: 1$.

If the Group II tumour patients are representative of the total male population as regards tobaccosmoking, and if the Group II tumours have no relationship to tobacco-smoking, it may be assumed that the remaining smokers in the male population, like the non-smokers and in the absence of any association between smoking and lung-cancer, would produce Group I tumours in numbers corresponding to the Group II tumours at each smoking level.

If these assumptions are accepted, a simple deduction of the Group II tumour cases from the Group I tumour cases, smoking level for smoking level, will reveal the number of Group I tumours associated with tobacco-smoking (Table X). It seems that in Norway, to-day, approximately only one out of every five cases of Group I lung tumours in males has no association with tobacco-smoking. This proportion is considerably higher than that estimated for England and Wales, since the figure of 17 per cent. calculated by Doll (1953) for the age group 25 to 74 years also included the Group II cases and all the female cases, but the smallness of the absolute figures for non-smokers introduces a certain inexactness into the present study.

Table $X$ also shows that in males smoking $4 \mathrm{~g}$. tobacco a day or less-equivalent to four cigarettesthe incidence of the two tumour groups is very like that in non-smokers; they do not develop more Group I tumours, and thus no relationship with smoking has been established. As soon, however, as the amount of smoking is increased above $5 \mathrm{mg}$. per day, the ratio of Group I to Group II tumours increases steadily, and reaches the very impressive level of $23: 1$ when the limit of $30 \mathrm{~g}$. a day has been passed (Table XI).

TABLE XI

RATIO OF GROUP I TO GROUP II TUMOURS BY SMOKING LEVELS (MALES)

\begin{tabular}{|c|c|c|c|}
\hline \multirow{2}{*}{$\underset{\text { (g.) }}{\text { Smoking Level }}$} & \multicolumn{2}{|c|}{ Group } & \multirow{2}{*}{$\begin{array}{l}\text { Ratio } \\
\text { I : II }\end{array}$} \\
\hline & I & II & \\
\hline $\begin{array}{c}0 \\
10-4 \\
5-19 \\
20+-9\end{array}$ & $\begin{array}{r}3 \\
4 \\
41 \\
107 \\
58 \\
23\end{array}$ & $\begin{array}{r}3 \\
5 \\
14 \\
17 \\
6 \\
1\end{array}$ & $\begin{array}{r:l}1 & 1 \\
0.8 & 1 \\
2 \cdot 9 & 1 \\
6 \cdot 3 & 1 \\
9 \cdot 7 & 1 \\
23 \cdot 0 & 1\end{array}$ \\
\hline
\end{tabular}

This does not only indicate a strong relationship between Group I lung carcinoma and smoking, but also shows the relative risks associated with different smoking levels. The figures are similar to those reported by Doll and Hill (1952), Levin (1954), Randig (1954), and Hamond and Horn (1955).

Whereas previous students of this problem have based their conclusions mainly upon the occurrence of all types of lung cancer, and have made their calculations on the basis of the population in general, the present study has utilized a totally different material for comparison. Here, the "control" material also consists of lung tumour patients, originally from the same sources as the material proper, and only separated from it by an histological analysis. This "control" material comes closer to the ideal material than any other. The present findings, therefore, strengthen considerably the conclusions of previous researchers. It would be strange, if another underlying primary factor should prove to be the real cause, and if the use of tobacco and the development of lung cancer should be two quantitively corresponding manifestations of such an unknown factor. At least, no such factor has been found, or even plausibly suggested.

The importance of the close association of fourfifths of the Group I tumours in males with tobaccosmoking should not, however, lead to neglect of other possible factors in the carcinogenic situation.

Tobacco-Smoking and Occupation.-A greater tendency to Group I lung cancer was observed in males with "dusty" occupations and trades, as well as in "clerical" and "professional" workers, as compared with men doing "open air" and "house" work, and it was emphasized that the dust, per se, might be of some importance.

A survey has been made of the smoking levels in males with Group I lung tumours according to their occupations (Table XII).* The material is, admittedly, small and accordingly difficult to analyse, but

TABLE XII

OCCUPATION OF MALES WITH GROUP I TUMOURS BY SMOKING LEVEL

\begin{tabular}{|c|c|c|c|c|c|c|c|c|c|c|c|}
\hline \multirow{2}{*}{$\begin{array}{l}\text { Occupa- } \\
\text { tional } \\
\text { Category }\end{array}$} & \multicolumn{10}{|c|}{ Smoking Level (g.) } & \multirow{2}{*}{$\begin{array}{l}\text { Ratio } \\
\text { I : II }\end{array}$} \\
\hline & 0 & 4 & 9 & 14 & 19 & 24 & 29 & 49 & + & Total & \\
\hline $\begin{array}{l}\text { "Open } \\
\text { Air" } \quad \text {.. }\end{array}$ & 3 & 2 & 13 & 24 & 5 & 6 & 5 & 2 & 2 & 62 & $2 \cdot 8: 1$ \\
\hline $\begin{array}{l}\text { "Clerical" } \\
\text { and "Pro- } \\
\text { fessional" }\end{array}$ & & & 8 & 11 & 15 & 5 & 4 & 10 & 2 & 55 & $6 \cdot 1: 1$ \\
\hline "Dusty" & & 2 & 20 & 43 & 9 & 9 & 6 & 6 & 1 & 96 & $6 \cdot 7: 1$ \\
\hline
\end{tabular}

- Sailors are included in Table XII. 
there seems to be no indication that the comparatively higher incidence of Group I tumours in males in "dusty" occupations is associated with an especially high smoking level. The figures may rather be interpreted to mean that "dusty" occupations may add another carcinogenic insult to the effect of the smoking. Theoretically, then, besides the wellknown lung carcinogenic agents, such as nickel, asbestos, coal tar, and uranium ore, certain "dusts" may also have an additive effect in the development of some cases of lung cancer, even if these agents are so weak as not to be easily or directly discovered. Exposure to metal dusts may especially be suspected. It is worth noting, however, that the 92 cases in "dusty" occupations include no non-smokers.

"Clerical" and "professional" workers among males with Group I tumours seem to be rather heavy smokers. Not one smoked less than $5 \mathrm{~g}$., only eight out of 53 patients smoked less than $10 \mathrm{~g}$. a day, and there were no non-smokers.

The "open air" and "house" workers represent the largest occupational category, but they show a low number of Group I tumour patients-only 62 cases in all. It seems that the smoking level is also generally lower than in the other occupational categories. This holds good not only for the relative number of smokers, but also for the amount smoked; all three non-smokers among the males with Group I tumours belong to this category.

Tobacco-Smoking and Domicile.-In this connexion it may be of interest to recall that, in the study of the geographical distribution of the Norwegian lung cancer material, it was observed that Group I tumours were more heavily represented in the "smaller non-industrial towns" with "fresh" air than in the "smaller industrial centres" with more or less "polluted" air. This finding was initially unexpected by the writer, through the predominant assumption that general air pollution has some importance for the development of lung cancer. The original paper comprised 235 cases of lung cancer, and figures of the present material, augmented to 300 cases, confirm the previous observation. The original "control" material gave no information as to smoking habits in different types of domicile, although the findings of more moderate smoking in rural districts was expected.

After the publication of the paper on geographical distribution, another material with a bearing on Norwegian smoking habits was placed at my disposal through the kindness of "Fakta", Oslo, an institute for marketing research, which had just completed a survey of one of our tobacco factories. Fig. 7 presents the proportions of smokers, as well

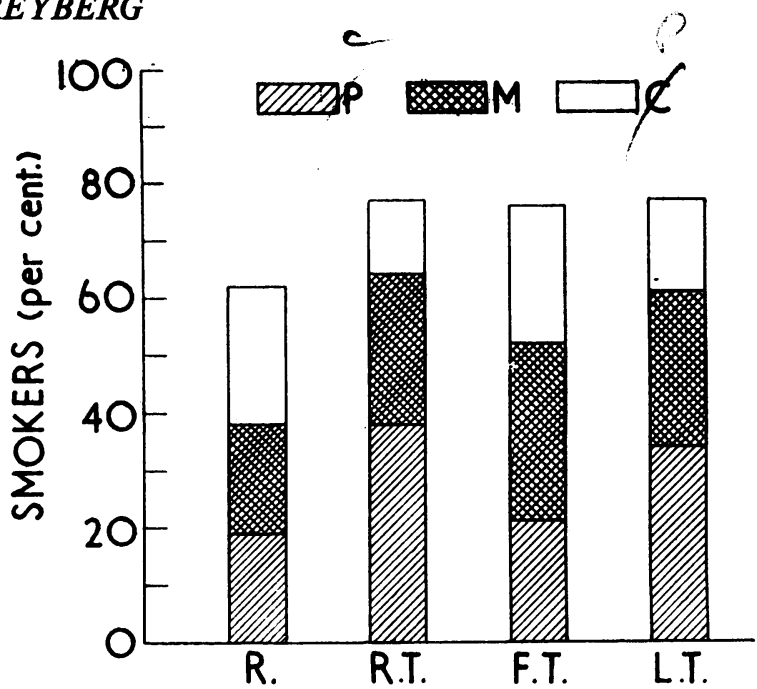

FIG. 7.-Smoking habits of males in different types of domicile (from "Fakta").

$$
\begin{aligned}
& \mathbf{P}=\text { pipe-smokers. } \\
& \mathbf{M} \text { = mixed pipe- and cigarette-smokers. } \\
& \mathbf{C} \text { = cigarette-smokers. } \\
& \mathbf{R} \text { = rural districts. } \\
& \text { T.R. = smaller non-industrial towns. } \\
& \mathbf{F} . \mathbf{T} \text { = smaller industrial centres. } \\
& \text { L.T. = larger towns. }
\end{aligned}
$$

as the different types of smoking in areas corresponding to our "rural districts", "smaller non-industrial towns", "smaller industrial centres", and "larger ? towns". The figures presented are not comparable to the figures of our original "control" material, because of the different criteria used. In our controls as well as in our lung cancer patients, a smoker was defined as "a person who has smoked as much as $1 \mathrm{~g}$. tobacco (in any form) daily for at least one year", whereas the "Fakta" material includes only current smokers. This explains the important differences in the percentages of smokers and non-smokers in the two series. The types of smoking in the different, geographical areas of the "Fakta" material are, however, comparable inter se, and Fig. 7 shows that smoking habits in the smaller towns differ markedly. The percentage of smokers is practically the same but the "smaller non-industrial towns", which are mainly commercial and administrative centres, show a considerably higher number of pure and mixed cigarette-smokers than the "smaller industrial centres", even if the average number of grammes smokes is the same.

The males with Group I tumours, in the present material also, show higher smoking levels in the smaller non-industrial towns than in the smaller industrial centres (Table XIII), opposite.*

\footnotetext{
* In Table XIII sailors have not been included.
} 
TABLE XIII

DOMICILE OF MALES WITH GROUP I TUMOURS BY SMOKING LEVEL

\begin{tabular}{l|r|r|r|r|r|r|r|r|r|r|r}
\hline Domicile & 0 & 4 & 9 & 14 & 19 & 24 & 29 & 49 & + & Total & I : II \\
\hline $\begin{array}{l}\text { Country- } \\
\text { side .. }\end{array}$ & 3 & & 7 & 10 & 4 & 4 & 5 & & & 31 & $1 \cdot 8: 1$ \\
\hline $\begin{array}{l}\text { Non- } \\
\text { Industrial } \\
\text { Towns .. }\end{array}$ & & & 10 & 16 & 3 & 3 & 4 & 8 & 1 & 45 & $5.6: 1$ \\
\hline $\begin{array}{l}\text { Industrial } \\
\text { Centres .. }\end{array}$ & & 2 & 3 & 11 & 5 & 2 & 1 & 2 & & 26 & $4 \cdot 3: 1$ \\
\hline $\begin{array}{l}\text { Larger } \\
\text { Towns .. }\end{array}$ & & 2 & 16 & 32 & 15 & 8 & 5 & 6 & 3 & 87 & $12 \cdot 4: 1$ \\
\hline
\end{tabular}

Types of Tobacco-Smoking.-Table XIV shows the types of smoking recorded for males with Group I and Group II tumours. There is a heavier representation of pure and mixed cigarette-smokers in Group I, and more pipe-smokers in Group II. The Group I series includes more smokers than the Norwegian "control" material presented by H. J. A. Kreyberg (1954). A detailed comparison with the "Fakta" material is useless, because of the different criteria used for non-smokers. The ratio of Group I to Group II tumours in pure pipe-smokers, pipe- and cigarette-smokers, and pure cigarette-smokers is shown in Table XV.

The absolute figures are small and the piçture is not completely clear, so that no precise conclusions can be drawn. On the average, the pure pipesmokers do not seem to use as much tobacco as the cigarette-smokers, and a quantitative factor may thus possibly also be of importance. It may, however, be worth calling attention to the apparent absence of increase in the ratio of Group I to Group II tumours in the pure pipe-smokers with the increasing amount of tobacco smoked, in contrast to the definite and systematic increase in the ratio when cigarette-smoking is involved. This may indicate that pure pipe-smoking does indeed carry a smaller risk of the development of lung cancer than cigarette-smoking.
TABLE XV

RATIO GROUP I TO GROUP II TUMOURS IN MALES BY TYPES OF SMOKING

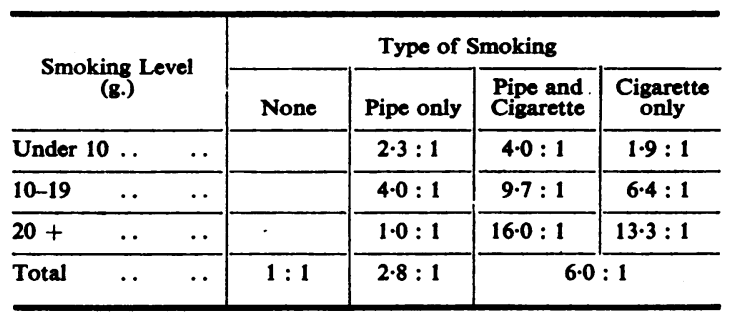

Tobacco-Smoking and Sex.-A striking feature of the Tables is the different sex incidence of some types of lung cancer, even among non-smokers. As there are many more female non-smokers, and as many females who are only very moderate smokers, the absolute figures cannot be compared. But, if the ratio of Group I tumours to Group II tumours is again used in analysing male and female nonsmokers (Table XVI), the result is a ratio of $1: 1$ in males (3:3 cases) and of $1: 9$ in females (3:27 cases).

TABLE XVI

RATIO OF GROUP I TUMOURS TO GROUP II TUMOURS BY SEA AND TOBACCO SMOKING

\begin{tabular}{|c|c|c|c|c|c|}
\hline \multirow{2}{*}{ Sex } & \multirow{2}{*}{\multicolumn{2}{|c|}{ Tobacco-Smoking }} & \multicolumn{2}{|c|}{ Group } & \multirow{2}{*}{$\begin{array}{l}\text { Ratio } \\
\text { I : II }\end{array}$} \\
\hline & & & I & II & \\
\hline Male & $\begin{array}{l}\text { Non-Smokers } \\
\text { Smokers }\end{array}$ & $\ldots$ & $\begin{array}{r}3 \\
210^{3}\end{array}$ & $\begin{array}{r}3 \\
42\end{array}$ & $\begin{array}{l}1: 1 \\
5: 1\end{array}$ \\
\hline Female & $\begin{array}{l}\text { Non-Smokers } \\
\text { Smokers }\end{array}$ & $\therefore$ & $\begin{array}{l}3 \\
2\end{array}$ & $\begin{array}{l}27 \\
10\end{array}$ & $1: 9$ \\
\hline
\end{tabular}

If the figures for smokers of less than $5 \mathrm{~g}$. tobacco, in whom no carcinogenic association was observed in our material (Table XI), are also included, the same picture appears: a ratio of $1: 1 \cdot 1$ in males ( $7: 8$ cases) and of $1: 7 \cdot 5$ in females ( $4: 30$ cases).

With due allowance for the smallness of the numbers, this indicates that, even among nonsmokers, males are predominant in Group $I$.

TABLE XIV

TYPES OF SMOKING IN GROUP I AND GROUP II TUMOUR PATIENTS AND SMOKING LEVELS

\begin{tabular}{|c|c|c|c|c|c|c|c|c|c|c|c|c|c|}
\hline \multirow{3}{*}{$\frac{\text { Group }}{I}$} & & & & \multicolumn{10}{|c|}{ Smoking Level (g.) } \\
\hline & \multicolumn{3}{|c|}{ Type of Smoking } & 0 & -4 & $5-9$ & $10-14$ & $15-19$ & $20-24$ & $25-29$ & $30-49$ & $50+$ & Total \\
\hline & $\begin{array}{l}\text { None .. } \\
\text { Pure Pipe } \\
\text { Pipe + Cigarette } \\
\text { Pure Cigarette }\end{array}$ & $\because$ & $\begin{array}{l}\ddot{*} \\
\ddot{*}\end{array}$ & $\begin{array}{l}3 \\
=\end{array}$ & $\frac{-3}{1}$ & $\begin{array}{l}\overline{11} \\
12 \\
18\end{array}$ & $\begin{array}{l}79 \\
18 \\
41\end{array}$ & $\begin{array}{l}\overline{1} \\
11 \\
17\end{array}$ & $\begin{array}{r}-2 \\
4 \\
14\end{array}$ & $\begin{array}{l}- \\
5 \\
10\end{array}$ & $\overline{-}$ & $\overline{7}$ & $\begin{array}{r}3 \\
36 \\
57 \\
117\end{array}$ \\
\hline II & $\begin{array}{l}\text { None } . . \\
\text { Pure Pipe } \quad \ldots \\
\text { Pipe + Cigarette } \\
\text { Pure Cigarette }\end{array}$ & $\because$ & $\begin{array}{l}\ddot{0} \\
\therefore\end{array}$ & $\begin{array}{l}3 \\
=\end{array}$ & $\overline{\overline{5}}$ & $\begin{array}{l}- \\
6 \\
3 \\
5\end{array}$ & $\begin{array}{l}-\overline{4} \\
2 \\
6\end{array}$ & $\begin{array}{c}-1 \\
1 \\
3\end{array}$ & $\frac{1}{-}$ & $\begin{array}{l}-1 \\
1 \\
2\end{array}$ & 二 & $\bar{z}$ & $\begin{array}{r}3 \\
13 \\
7 \\
22\end{array}$ \\
\hline
\end{tabular}


Wynder (1954), in his Table VI derived from his own material and from the literature, shows the occurrence of types of lung cancer (very much like our own grouping) in non-smoking males; this material gives a ratio of $2.4: 1$ (34 "Epidermoid": 14 "Adenocarcinoma"), which is a very low ratio, even if not as low as the Norwegian one quoted above.

The fact that Wynder's collected material only concerns "Epidermoid" (including "oat-cell" carcinomata) and "Adenocarcinomata" (including bronchiolar cell carcinomata) partly explains the difference from the present material, in which the Group II tumours also include adenomata and salivary gland tumours. If the latter are omitted from the present material, we find a ratio of $1.8: 1$ for males ( $7: 4$ cases).

The ratio in females in our material is $0 \cdot 1: 1$ (3 Group I : 27 Group II in non-smokers), and by Wynder's classification the ratio is $0 \cdot 15: 1$ (3 Group I : 20 Group II).

These figures may appear to contradict the statement by Doll (1953) that "the incidence of lung cancer in non-smokers may be the same in men and in women and in residents in areas of different density of population", a statement with which Wynder agrees.

Possibly, however, these different statements may be reconciled. It should be emphasized that this marked sex difference in the Norwegian material applies to Group I tumours only. If the figures from Table $\mathrm{XVI}$ are used to compare all types of lung cancer seen as an entity-and that is the background of Doll's analysis-one finds a total of six "lung cancers" $(3+3)$ in the non-smoking males and thirty $(3+27)$ in the non-smoking females. As the non-smoking females in the population, however, are much more numerous than the non-smoking males, a factor of 5 is very probable according to our previously quoted figures, and one arrives at an approximately equal sex incidence of "lung cancer" among non-smokers.

As Group I tumours in the Norwegian material are rather uncommon among females as well as among non-smoking males, the peculiar sex difference in the incidence of the Group I tumours is easily obscured by the much greater number of Group II tumours, if special attention is not paid to the histological typing, followed by a separate treatment of the two groups. Thus the value of the full application of this analytical procedure has again been demonstrated.

This means that the possibility of a special sex disposition to the development of Group I tumours in males cannot be denied. Whether this disposition is based upon architectural differences in the gross anatomy of the lungs, upon different biological responses of the epithelium, or upon hormonal factors, is completely unknown; the question cannot yet be tackled by clinical and experimental methods, though gross anatomical studies might very well be made.

\section{SUMmARY AND CONCLUSIONS}

It has been shown that the increase in lung cancer in males which has taken place in Norway in the 20th century closely follows the pattern of development in a number of other countries, though delayed by a decade or two.

At first a very slow and parallel rise was seen in the number of cases of lung cancer reported in males and females, but gradually, and from the mid 1930's especially, the increase in male cases has greatly exceeded the increase in female cases. This sex difference is almost entirely confined to urban areas.

A study of the histological types of lung cancer has revealed that, from the time of the more pronounced increase in male cases, the relative frequency of the histological types also changed, with a steadily increasing number of male cases of Group I tumours (squamous cell, large cell, and small cell carcinomata). No such change was found in male cases of Group II tumours (adenomata, bronchiolar cell carcinomata, adenocarcinomata, or salivary gland tumours), or in females of either group. It is concluded that almost the whole of the reported increase in female cases, as well as part of the increase in male cases, is due to better diagnostic facilities, whereas the specific increase in Group I tumour cases in males is due to a real increase in the number of lung tumours. This means that a new carcinogenic situation manifested itself in Norway in the mid 1930s. Since these Group I tumour cases in males have a period of development ranging between 20 and 40 years or more, this new carcinogenic situation must have begun to arise at the beginning of the 20th century. It has been manifested, up to the present, in male patients in urban areas. From theoretical considerations, as well as from our special studies, it is thought unlikely to be due to general air pollution, although the new carcinogenic situation is mainly observed in urban areas. The main active principle(s) is (are) most probably connected with male working conditions and/or life habits.

It is well known that certain industrial processes dealing with radio-active material, nickel, asbestos, and coal tar are associated with an increased rate of lung cancer. The Norwegian material does not, however, show any special trade or occupation which carries a risk so marked that the increased 
incidence of Group I tumour cases in males can be explained by occupational hazards.

Males in "dusty" occupations generally have an increased lung cancer frequency, as compared with "open air" workers, but the risk is nearly as great among "clerical" and "professional" workers.

The tobacco-smoking habits of 300 Group I and Group II lung cancer cases (213 males and 5 females in Group I, and 45 males and 37 females in Group II) have been investigated and compared with those of the general population, and the main conclusions are as follows:

(1) As no differences have been found, either in males or in females, between the smoking habits of the Group II tumour patients and the smoking habits of the population in general, it is concluded that tobaccosmoking has no relation to the occurrence of Group II lung tumours. Such tumours represent, in Norway today, nearly 90 per cent. of all female lung tumour cases, but less than 20 per cent. of all male cases.

(2) As considerably fewer non-smokers are found among the males with Group I lung tumours than among those with Group II tumours or than among the corresponding male "control" material, and as the ratio of Group I to Group II cases increases steadily with the amount of tobacco smoked, it is concluded that tobacco-smoking is closely related to the development of a considerable proportion of Group I lung tumour cases in males. The very limited female material does not contradict this conclusion.

(3) As a certain number of Group I tumours occur in male and female non-smokers, it is concluded that not all Group I tumour cases are related to, or influenced by, tobacco-smoking.

(4) From an analysis of the ratio of Group I to Group II tumours in males, it has been calculated that, in Norway at present, four out of five cases of Group I lung tumours in males are related to tobacco-smoking, and that one out of five arises from causes unrelated to tobacco-smoking.

(5) As males doing "dusty" work show a greater number of Group I lung tumours, in spite of more moderate tobacco consumption, than males doing "clerical" and "professional" work, it is tentatively suggested that industrial dusts and fumes may aggravate the injury caused by tobacco-smoking.

(6) A previously reported finding, that relatively more Group I tumour cases occur in males in smaller non-industrial towns (administrative and commercial centres) with "fresh" air than in smaller industrial centres with more or less "polluted" air, may be explained by the fact that the former type of community includes more cigarette-smokers.

(7) The relationship of lung cancer development to pipe-smoking, if present at all, is less marked than its relationship to cigarette-smoking.

(8) The ratio of Group I to Group II tumours in nonsmokers is nine times greater in males than in females. This great difference per se, besides the fact that the only three males with Group I tumours in the present material who were non-smokers were among the "open air" workers, makes it difficult to ascribe the whole sex difference to external factors alone. A biological sex difference, architectural and/or biochemical, influencing the response of the lungs to some, or all, carcinogenic agents, cannot be excluded.

In the light of this discussion and of the conclusions presented, it may be of interest to emphasize the following points:

(1) The conclusions are based upon a special histological subdivision of "lung cancer" material, according to certain definite criteria. If the grouping and the criteria used are not followed, the same results can accordingly not be obtained. An off-hand dismissal of the possibility of making a sufficiently precise histological grouping is contradicted by the results. Not every case can be grouped with certainty, but most cases can.

(2) The results of the present study are so consistent and so clear, that it is unreasonable not to regard them as expressions of true conditions. An artefact with such a degree of consistency is most improbable.

(3) The figures quoted represent trends and relationships only. They do not express fixed mathematical correlations, generally applicable, but refer to conditions in Norway during the period of investigation. They cannot be applied to other countries and other conditions without further qualification. Differences in types of tobacco smoked, and in the amount and degree of smoking, differences in the surrounding air (in general or in workshops), and probably also constitutional differences, may cause minor quantitative variations in the effects, but the trends of these general conclusions I do regard as generally valid.

These studies have been supported by a generous grant from "Tobaksfabrikernes Landsforening av 1901". 


\section{REFERENCES}

Christiansen, T. (1953). Brit. J. Cancer, 7, 428.

Doll, R. (1953). Ibid., 7, 303.

- and Hill, A. B. (1952). Brit. med. J., 2, 1271.

Hamond, E. C. and Horn, D. (1955). "Annual Meeting of the American Medical Association in Atlantic City, June 6, 1955". (unpublished).

Harbitz, F. (1937). Norsk Mag. Laegevid., 98, 1451.

Jakobsen, A. (1953). Brit. J. Cancer, 7, 423.

Korteweg, R. (1951). Ibid., 5, 21.

Kreyberg H. J. A. (1954) Ibid $8,13$.

Levin, M. L. (1954). N. Y. St. J. Med., 54, 769.

Lickint, F. (1953). "Ätiologie und Prophylaxe des Lungenkrebses". Steinkopff, Dresden and Leipzig.
Randig, K. (1954). Öff. GesundhDienst., 16, 305.

Stocks, P. and Campbell, J. M. (1955), Brit. med. J., 2, 923.

Wynder, E. L. (1954). Penn. med. J., 57, 1073.

\section{ADDITIONAL BIBLIOGRAPHY}

Kreyberg, L. (1952). Brit. J. Cancer, 6, 112.

1954a). Ibid., 8, 199

(1954b). Jbid, $8,209$.

1954c). Ibid. $8,599$.

(1954d). Ibid., 8, 605 . 


\section{CORRIGENDA}

The paper entitled "Occurrence and Aetiology of Lung Cancer in Norway in the Light of Pathological Anatomy" by Leiv Kreyberg, which appeared in the October (1956) issue of the Journal, vol. 10, p. 145, contains two errors:

(1) In the key to Figure 7 (p. 154) the letters "P" and " $C$ " have been transposed. The same error appears in the same author's paper on "Lung Cancer and Tobacco Smoking in Norway" published in the British Journal of Cancer (1955), 9, 495 (Diagram p. 504), from which the illustration in this Journal was taken. The figures which form the basis of the diagram are given in Table III of the Appendix in the British Journal of Cancer, 9, 510.

(2) Table XII (p. 153) should read as follows:

OCCUPATION OF MALES WITH GROUP I TUMOURS BY SMOKING LEVEL

\begin{tabular}{l|c|c|c|c|c|c|c|c|c|c|c}
\hline $\begin{array}{l}\text { Occupational } \\
\text { Category }\end{array}$ & 0 & 4 & 9 & 14 & 19 & 24 & 29 & 49 & $50+$ & Total & $\begin{array}{c}\text { Ratio } \\
\text { I:II }\end{array}$ \\
\hline "Open Air" & 3 & 2 & 13 & 24 & 5 & 6 & 5 & 2 & 2 & 62 & $1: 2 \cdot 9$ \\
\hline $\begin{array}{l}\text { "Clerical and } \\
\text { Professional" }\end{array}$ & & & 6 & 11 & 15 & 5 & 4 & 10 & 2 & 53 & $1: 5 \cdot 9$ \\
\hline "Dusty" .. & & 2 & 22 & 43 & 9 & 9 & 6 & 6 & 1 & 98 & $1: 6 \cdot 5$ \\
\hline
\end{tabular}

Two errors in Table XII were caused by transferring two "waiters" from the "Clerical and Professional" category to the "Dusty" category. Accordingly, in the text (on p. 154, 1. 14) one should read 98 instead of 92 , and (on 1. 18) six instead of eight. 